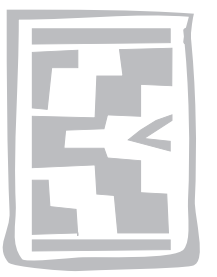

\title{
Molecular analysis of bovine viral diarrhoea virus isolates from South Africa
}

\author{
N. KABONGO ${ }^{1,2}$, C. BAULE ${ }^{3}$ and M. VAN VUUREN ${ }^{1}$
}

\begin{abstract}
KABONGO, N., BAULE, C. \& VAN VUUREN, M. 2003. Molecular analysis of bovine viral diarrhoea virus isolates from South Africa. Onderstepoort Journal of Veterinary Research, 70:273-279

The presence of bovine viral diarrhoea virus in South Africa has been confirmed by several serological surveys. However, little is known about its biological properties. Twenty five isolates obtained by isolation in tissue culture and detected by means of the antigen capture ELISA from clinically sick cattle and from foetal calf serum in South Africa were characterized on the basis of analysis of the 5' non-translated (NTR) region of the genome. A reverse-transcription polymerase chain reaction (RT-PCR) was used to amplify specific sequences from the 5'NTR of the genome. The oligonucleotide primers corresponding to positions $105-125$ and 399-378, respectively, in the sequence of BVDV strain NADL were used to generate the PCR products. Both strands were sequenced directly with these primers and fluorescence-labelled dideoxynucleotides in an automated nucleic acid sequencer. Reference strains of pestiviruses [(BVDV type I, BVDV type II, border disease virus (BDV) and hog cholera virus (HCV)] and isolates from a previous investigation on BVDV in southern Africa were included for comparative purposes.
\end{abstract}

All the BVDV strains obtained during this study belong to subgroups of BVDV genotype I. No association could be demonstrated between the geographic origin of the isolates. A number of isolates formed another branch separate from the existing branches la, Ib and Ic. These findings suggest that extensive genetic diversity can be found within BVDV type I isolates from southern Africa. Isolates that group with the classical BVDV type I strains, particularly of American origin, coexist with variants that appear to represent a local genetic pool and or variants evolving from the classical strains.

Keywords: BVDV 5'NTR, phylogeny, reverse-transcription polymerase chain reaction, sequencing, South Africa

\section{INTRODUCTION}

Bovine viral diarrhoea virus (BVDV) is a pathogen of cattle with a worldwide distribution. It causes a

1 Department of Veterinary Tropical Diseases, Faculty of Veterinary Science, University of Pretoria, Private Bag X04, Onderstepoort, 0110 South Africa

2 Bacteriology Division, Onderstepoort Veterinary Institute, Agricultural Research Council, Private Bag X05, Onderstepoort, 0110 South Africa

3 Swedish University of Agricultural Sciences, Veterinary Faculty, Department of Veterinary Microbiology, Section of Virology, Biomedical Center, Box 585, S-751 23 Uppsala, Sweden

Accepted for publication 12 May 2003-Editor variety of prenatal and postnatal clinical syndromes. Together with the viruses of border disease (BD) and hog cholera $(\mathrm{HC})$ it forms the genus Pestivirus within the family Flaviviridae (Horzinek 1991; Collett 1992).

The genome of BVDV is a single-stranded, positivesense, non-polyadenilated RNA of approximately $12.5 \mathrm{~Kb}$ in length. It has two non-coding regions at the 5' end (5'NTR) and at the $3^{\prime}$ end (3'NTR) of the genome. Translation occurs in a cap-independent manner from a single large open reading frame (ORF) that encodes a polyprotein of about 4000 amino acids. The polyprotein is co- and post-translationally processed by viral and host cell proteases 
into mature structural and non-structural proteins. The BVDV genome encodes four structural proteins: capsid protein $(\mathrm{C})$, envelope protein with intrinsic RNase activity $\left(E^{\text {rns }}\right)$, transmembrane glycoprotein (E1) and envelope glycoprotein (E2). At least seven non-structural proteins (N pro, p7, NS2-NS3, NS4 A, NS4 B, NS5 A and NS5 B) are found (Collett 1996; Thiel, Plagemann \& Moennig 1996). The 5'NTR of the genome is highly conserved among pestiviruses and for this reason it has been used as a target for molecular detection of pestiviruses and for genetic discrimination among and within pestivirus genotypes (Pellerin, Vandenhurk, Lecomte \& Tijssen 1994; Lowings, Ibata, Needham \& Paton 1996; Baule, Van Vuuren, Lowings \& Belák 1997; Becher, Orlich, Shannon, Horner, Konig \& Thiel 1997; Vilcek, Alenius, Paton, Mittelholzer \& Belák 1999).

Two genotypes of BVDV have been described on the basis of the 5'NTR analysis, namely BVDV type I, which is subdivided into subgroup la and represented by the reference strain NADL, and subgroup $\mathrm{lb}$, represented by the reference strain Osloss. BVDV type II has strain 890 as reference and comprises especially isolates associated with a new form of acute infection in cattle, the haemorrhagic syndrome, originally described in North America (Pellerin et al. 1994). BVDV type II has also been shown to include ovine isolates (Vilcek, Nettleton, Paton \& Belák 1997; Ridpath, Neil, Frey, Landgraft \& Thiel 2000); and, recently, to be present outside North America (Canal, Strasser, Hertig, Masuda \& Peterhans 1998; Dean \& Leyh 1999; Flores, Weiblen, Gil, Tobias, Lima, Garcez \& Botton 2000).

The natural transmission of pestiviruses which are not highly host specific between hostspecies has prompted a new classification of the members of the Pestivirus genus. The suggested classification takes into account the antigenic and genomic relationship rather than the species of origin (Becher et al. 1997; Sullivan, Chang \& Akkina 1997; Vilcek et al. 1997). Accordingly, the genus Pestivirus is divided into four genotypes: genotype 1 (Pestivirus type 1) that includes the present BVDV type I strains; genotype 2 (Pestivirus type 2) represents isolates of HCV; genotype 3 (Pestivirus type 3) includes sheep and pig isolates defined as "true BD" viruses and genotype 4 (Pestivirus 4) includes isolates of cattle and sheep currently defined as BVDV type II.

The presence of BVDV in southern Africa has been confirmed by several serological surveys (Theodoridis, Boshoff \& Botha 1973; Theodoridis \& Boshoff 1974; Barnard 1977; Depner, Hubschle \& Liess 1991; Giangaspero, Alders, Baer, Blondel \& Mor- gan 1991; Van Vuuren 1991; Baule \& Banze 1994; Muvavarirwa, Mudenge, Moyo \& Javangwe 1995; Ferreira, Lourens \& Van Vuuren 2000). However, little is known about its biological properties.

The aim of this paper was to expand knowledge on the genetic characteristics of local isolates and those from the previous study by Baule et al. (1997).

\section{MATERIALS AND METHODS}

\section{Specimens}

Specimens of blood, organs and lymphoid tissues from sick and dead cattle were obtained from feedlots, commercial beef farms and dairy farms or were submitted by private practitioners and feedlot consultants. Other specimens comprised cell lines ( $n=3$ ) submitted for testing for the presence of adventitious viruses, and pooled serum obtained from foetuses $(n=7)$ at an abattoir. Some specimens were tested in duplicate, which accounts for the total number of 117 (Table 1).

Tissue filtrates of the original specimens or sera were inoculated either on Madin Darby Bovine Kidney (MDBK) line cells or primary and secondary cells calf foetal kidney cells (CFK). The viruses that were isolated, were identified by means of specific fluorescein-conjugated antisera and antigen capture ELISA tests.

\section{RT-P C R of the 5'NTR of the BVDV genome}

Total RNA was extracted from supernatants of infected cells, tissue homogenates and serum specimens, using TRIzol (Gibco, Life Technologies), according to the manufacturer's instructions. cDNA was synthesized by random priming with pdN6 (Amersham-Pharmacia, Uppsala, Sweden) using Moloney murine leukaemia virus reverse transcriptase (M-MLV RT) (Gibco, Life Technologies), as follows: $5 \mu \ell$ of total RNA were mixed with $0.02 \mathrm{U}$ of pdN6 and $3 \mu \ell$ of $\mathrm{ddH}_{2} \mathrm{O}$ and denatured at $65^{\circ} \mathrm{C}$ for $10 \mathrm{~min}$, then quickly chilled on ice. A reaction mix containing $4 \mu \ell$ of $5 \times 1^{\text {st }}$ strand buffer, $2 \mu \ell$ of $0.1 \mathrm{M}$ DTT, $0.5 \mu \ell$ of each dNTP (10 mM each), $24 U$ of RNAse inhibitor (RNA guard, Amersham-Pharmacia) and $200 \mathrm{U}$ of M-MLV RT was added. Synthesis was carried out at $37^{\circ} \mathrm{C}$ for $90 \mathrm{~min}$, followed by the inactivation of the enzyme at $95^{\circ} \mathrm{C}$ for $5 \mathrm{~min}$.

A polymerase chain reaction (PCR) was used to amplify specific sequences from the 5'NTR of the genome. The oligonucleotide primers used were as 
follows (corresponding to positions 105-125 and 399-378, respectively, in the sequence of BVDV strain NADL):

Forward - 5'-AGCCATGCCCTTAGTAGGACT-3' Reverse - 5'-ACTCCATGTGCCATGTACA-3'

Amplification was carried out in a total volume of 50 $\mu \ell$ containing $10 \mathrm{mM}$ Tris- $\mathrm{HCl}, \mathrm{pH} 9.0,50 \mathrm{mM} \mathrm{KCl}$, $1 \mu \mathrm{g} / \mu \ell$ of BSA, $0.2 \mathrm{mM}$ of each deoxynucleotide, $15 \mathrm{pmol}$ of each primer, $2.5 \mathrm{mM} \mathrm{MgCl}, 2.5 \%$ Formamide, $1 \mathrm{U}$ of Taq DNA polymerase (Perkin ElmerCetus, Norwalk, CA, USA), and $5 \mu \ell$ of cDNA. The reaction mixes were overlaid with two drops of mineral oil. PCR cycles were as follows: 5 cycles of denaturation at $94^{\circ} \mathrm{C}$ for $45 \mathrm{~s}$, annealing at $55^{\circ} \mathrm{C}$ for $45 \mathrm{~s}$ and extension at $72^{\circ} \mathrm{C}$ for $1 \mathrm{~min}$, followed by 30 cycles of denaturation at $94^{\circ} \mathrm{C}$ for $45 \mathrm{~s}$, annealing at $50^{\circ} \mathrm{C}$ for $45 \mathrm{~s}$ and extension at $72^{\circ} \mathrm{C}$ for $1 \mathrm{~min}$. A final extension step at $72^{\circ} \mathrm{C}$ for 7 min was included. Precautions to avoid contamination as described by Belák \& Ballagi-Pordány (1993) were followed throughout the RT-PCR. The PCR products were visualized by ethidium bromide staining, after electrophoresis on $2 \%$ agarose gels.

\section{Sequencing and sequence analysis}

The amplicons were purified using the QIAquick DNA purification kit (Qiagen), according to the manufacturer's instructions and spectrophotometrically quantified. Both strands were sequenced directly with the same primers used to generate the PCR products and fluorescence-labelled dideoxynucleotides in an automated nucleic acid sequencer (ABI PRISM 377). The primers were selected based on alignments of sequences of various pestiviruses (BVDV type I, CSFV and BDV). Highly conserved parts of the 5'NTR were used for the selection of primers. These primers have also been evaluated for the amplification of BVDV type II as well and were therefore suitable for the detection of all known pestiviruses.

Nucleotide sequence editing, analysis and alignments were done using multiple programmes from the DNAstar package (DNASTAR Inc., Madison, Wi.). The phylogenetic analysis presented was completed following alignment of nucleotide sequences using the Megalign. Reference strains of pestiviruses, NADL-BVDV type I, subgroup la (American type), Osloss-BVDV type I, subgroup lb (European type), 890-BVDV type II, BDV and HCV and isolates Ic from a previous investigation on BVDV in southern Africa (Baule et al. 1997) were included for comparative purposes. The criteria for assign- ment of genotype were based on sequence similarity as shown in the phylogenetic tree. Strains branching with or similarly to NADL are considered subgroup la, with Osloss subgroup lb and so forth. The EMBL/Genbank/DDBJ for the nucleotide sequences corresponding accession numbers are: AF041040, M31182, M96751, M96687, L32885, L32888 and sequences selected from U97409-U97481. The phylogenetic tree was edited with the Deneba Canvas (5.0) graphic programme.

\section{RESULTS}

A total of 117 specimens were subjected to molecular characterization of which 25 were confirmed positive with PCR (Table 1). Eighteen isolates obtained by isolation in tissue culture and seven isolates detected in foetal calf sera by means of the antigen capture ELISA were confirmed as BVDV with PCR. Eight other specimens that included two sera, three buffy coats, two spleens and one lung gave inconclusive readings with the FA test in cell cultures. Two were confirmed negative and six yielded a weak band with PCR. They were not molecularly analyzed and were not included in the phylogenetic tree (Fig. 1).

All of the strains were identified as BVDV I, either subgroups BVDV la (NADL-like) or BVDV Ib (Osloss-like) or BVDV I*.

Table 2 shows isolates that were confirmed by PCR and the predominant clinical signs associated with them. Seven isolates obtained from 156 pooled serum specimens and three cells lines of unknown history were included under the heading "others", since no clinical syndrome could be ascribed to them.

The phylogenetic assignment of these isolates, compared to reference strains of pestiviruses and to sequences from a previous investigation with BVDV isolates from southern Africa is shown in Fig. 1. The phylogenetic tree was generated based on a comparison of 245 nucleotide long sequences in the 5'NTR. The distances were calculated using the neighbor-joining method. The BVDV isolates listed in Fig. 1 were determined to be BVDV type I. The 25 isolates analyzed were phylogenetically discriminated as follows: two (ST22F/99, ST2G/99), segregated clearly as subgroup la; none was found under subgroup lb; three (ST25G/99, ST23F/99, ST24G/99) were included in a cluster provisionally termed Ic (Baule et al. 1997), whilst the remaining isolates formed a separate cluster named $\mathrm{I}^{*}$. 
FIG. 1 Phylogenetic analysis of BVDV isolates and sequences from Genbank Reference strains of BVDV type I (NADL, OSLOSS), BVDV type II (890), BDV, HCV and isolates from a previous investigation on BVDV are included. Isolates obtained during the present investigation are indicated in bold. The phylogeny is based on analysis of $5^{\prime}$ NTR of the genome. The isolates (see Table 2) cluster into subgroup la, subgroup Ic and subgroup I*

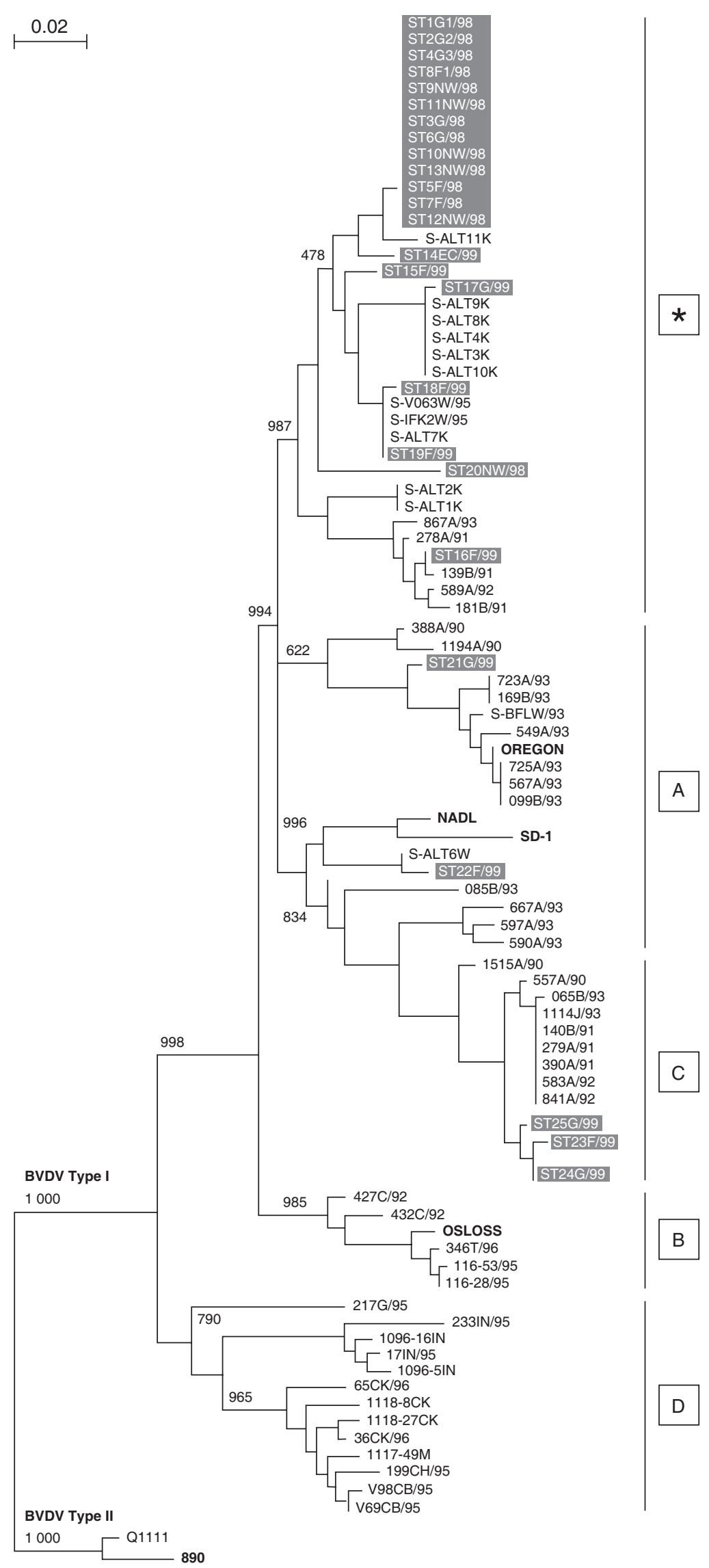


TABLE 1 BVDV isolates obtained by virus isolation, ELISA and confirmed with PCR

\begin{tabular}{|l|l|l|l|l|}
\hline Specimens & Number & ELISA positive & Virus isolation positive & PCR positive \\
\hline Serum & 54 & 7 & 4 & 11 \\
Whole blood & 32 & 3 & 3 & 3 \\
Spleen & 10 & NT & 3 & 3 \\
Lung & 8 & NT & 2 & 2 \\
Lymph nodes & NT & NT & 3 & 3 \\
Cell lines & 3 & 7 & 18 & 3 \\
\hline Total & 117 & 7 & 25 \\
\hline
\end{tabular}

NT: Not tested

* Three buffy coats that tested positive on both tests

TABLE 2 Predominant clinical syndrome associated with BVDV isolates and their origin

\begin{tabular}{|c|c|c|c|c|}
\hline $\begin{array}{l}\text { Respiratory } \\
\text { +Pyrexia } \\
(n=7)\end{array}$ & $\begin{array}{l}\text { Respiratory } \\
(n=3)\end{array}$ & $\begin{array}{l}\text { Diarrhoea } \\
+ \text { Pyrexia } \\
(n=3)\end{array}$ & $\begin{array}{l}\text { Diarrhoea } \\
(n=2)\end{array}$ & $\begin{array}{l}\text { Others } \\
(n=10)\end{array}$ \\
\hline $\begin{array}{l}\text { ncpST5F/98 } \\
\text { ncpST6G/98 } \\
\text { ncpST7F/98 } \\
\text { ncpST8F/98 } \\
\text { ncpST21G/98 } \\
\text { ncpST9NW/98 } \\
\text { ncpST10NW/98 }\end{array}$ & $\begin{array}{l}\text { ncpST11NW/98 } \\
\text { ncpST12NW/98 } \\
\text { ncpST13NW/98 }\end{array}$ & $\begin{array}{l}\text { ncpST1G1/98 } \\
\text { ncpST2G2/98 } \\
\text { ncpST4G/98 }\end{array}$ & $\begin{array}{l}\text { nсpST3G/98 } \\
\text { ncpST17G/99 }\end{array}$ & $\begin{array}{l}\text { ncpST14EC/99 } \\
\text { ncpST15F/99 } \\
\text { ncpST16F/99 } \\
\text { ncpST18F/99 } \\
\text { ncpST19F/99 } \\
\text { ncpST20NW/98 } \\
\text { ncpST22F/99 } \\
\text { ncpST23F/99 } \\
\text { ncpST24G/99 } \\
\text { ncpST25G/99 }\end{array}$ \\
\hline
\end{tabular}

ncp: noncytopathogenic

* This classification is based on the predominant clinical signs observed by the clinician in naturally infected animals. The enteric syndrome manifests as acute or chronic diarrhoea; and the respiratory syndrome as nasal discharge, respiratory distress, sneezing and coughing, while "others" include those of unknown history and those in which no clinical syndrome ascribed to the case

** Identification of isolates: ncp: noncytopathic biotype, followed by S for South Africa, $T$ for tropical diseases, the isolate ID and the area where it came from, the number after province of origin, where applicable, represents number of samples from the same sender in order of submission, which is followed by year of isolation. The letters that represent the province of origin: NW: North-West; F: Free State; EC: Eastern Cape; G: Gauteng

\section{DISCUSSION}

There was no relationship between the geographic origin, the nature of the clinical signs and the typing of the BVDV isolates. Animals from the North-West (NW); Free State (F); G (Gauteng) and Eastern Cape (EC) Provinces were infected with the same strain. This may inter alia be the result of the free movement of animals, the absence of closed herds or vaccination. Throughout South Africa, there is a diversity of farming systems from extensive to intensive, including closed herds where artificial insemination (Al) is used. Isolates were obtained from samples collected in feedlots, dairy herds and commercial beef farms in all provinces, indicating the ubiquitousness of BVDV in South Africa.
The reverse-transcription PCR based on the 5'NTR of the virus genome and further sequencing enabled differentiation of BVDV genotypes and subgroups; this is of epidemiological importance and might be of value in control programmes. It has been reported that direct detection of the virus in serum or homogenized tissue specimens clinical samples by RT-PCR is often unsuccessful (ElKholy, Bolin, Ridpath, Arab, Abou-Zeid, Hamman \& Platt 1998). This might be due to either the presence of certain elements in the clinical specimens that are inhibitory to reverse transcriptase or taq polymerase enzymes or to masking of the target template by proteins coagulated during extraction of nucleic acids in the clinical specimens. 
Six clinical samples from which virus had not been isolated showed a weak band with RT-PCR although it was situated at the correct molecular weight position. These six specimens were not molecularly analyzed nor were they included in the phylogenetic tree. The results obtained with PCR were in agreement with those obtained by virus isolation in all the negative cases except in seven out of 156 pooled sera that were negative for virus isolation after one passage but tested positive on antigen capture ELISA. This confirms the need for more than one passage before virus becomes detectable with the FA test.

All the BVDV strains obtained during this study were ncp BVDV I (BVDV la (NADL-like), BVDV Ic subgroups or BVDV I* although Theodoris isolated cp BVDV in 1974. No association could be demonstrated between the geographic origin of the isolates and branch discrimination. The three groupings formed by the South African isolates (subgroup la, cluster Ic and cluster provisionally called I*) included BVD viruses from different regions: $F, G$, NW and EC. It is worth noting their similarity to isolates of the BVDV cluster provisionally termed Ic in a previous investigation (Baule et al. 1997) which did not segregate with either the la or the Ib subgroups. The presence of isolates of this cluster in South Africa may reflect a local genetic subgroup that is spreading in the region since genotype I shows an intragenotyping diversity. This might have occurred because of cattle movement or the use of biological such as cell culture-derived vaccines. No type BVDV type II were found, however the vaccine appears to be protective against both types I and II.

A number of isolates $I^{*}(n=20)$ formed another branch separate from la, lb or Ic. This branch was, however; distinct from the one defining a cluster preliminary termed Id by Baule et al. (1997) and was found to comprise isolates particularly distinct from the la and Ib subgroups. These findings suggest that an extensive genetic diversity can be found within BVDV type I isolate from southern Africa. Isolates that group with the classical BVDV type I strains, particularly of American origin, coexist with variants that appear to represent a local genetic pool and/ or variants evolving from the classical strains.

A clustering of isolates with regards to farms of origin was not observed with the isolates investigated, as has been reported by others (Paton 1995; Vilcek et al. 1999). Differences in farming practices, i.e. extensive farming versus intensive farming may con- tribute to this difference in virus ecology. Closed herds and restricted contact among cattle may be a determinant factor to establish BVDV in a herdspecific manner. Most herds from which the samples originated were managed extensively.

\section{REFERENCES}

BARNARD, B.J.H. 1977. Virus diseases in feedlot cattle in South Africa. Bulletin de l' Office International des Epizooties, 88:153-160.

BAULE, C. \& BANZE, J. 1994. Bovine virus diarrhoea virus infections in calves from selected farms in Mozambique. Bulletin of Animal Health and Production in Africa, 42:280286.

BAULE, C., VAN VUUREN, M., LOWINGS, J.P. \& BELÁK, S. 1997. Genetic heterogeneity of bovine viral diarrhoea viruses isolated in southern Africa. Virus Research, 52:205-220.

BECHER, P., ORLICH, M., SHANNON, A.D., HORNER, G., KÖNIG, M. \& THIEL, H.J. 1997. Phylogenetic analysis of pestiviruses from domestic and wild ruminants. Journal of General Virology, 78:1357-1366.

BELÁK, S. \& BALLAGI-PORDÁNY, A. 1993. Experiences on the application of the polymerase chain reaction in a diagnostic laboratory. Molecular and Cellular Probes, 7:241-248.

CANAL, C.W., STRASSER, M.N., HERTIG. C., MASUDA, A. \& PETERHANS, E. 1998. Detection of antibodies to bovine viral diarrhoea virus (BVDV) and characterization of genomes of BVDV from Brazil. Veterinary Microbiology, 63: 85-97.

COLLETT, M.S. 1992. Molecular genetics of pestiviruses. Comparative Immunology Microbiology and Infectious Diseases, 15:145-154.

COLLETT, M.S. 1996. Genomic structure of BVDV. Proceedings of an linternational Symposium on Bovine Viral Diarrhoea Vvirus, Cornell University, 1996: 18-23.

DEAN, H.J. \& LEYH, R. 1999. Cross-protective efficacy of a bovine viral diarrhea virus (BVDV) type 1 vaccine against BVDV type 2 challenge. Vaccine, 17:1117-1124.

DEPNER, K., HUBSCHLE, O.J.B. \& LIESS, B. 1991. Prevalence of ruminant pestivirus infections in Namibia. Onderstepoort Journal of Veterinary Research, 58:107-109.

EL-KHOLY, A.A., BOLIN, S.R., RIDPATH, J.F., ARAB, R.M.H., ABOU-ZEID, A.A., HAMMAM, H.M. \& PLATT, K.B. 1998. Use of polymerase chain reaction to simultaneously detect and type bovine viral diarrhoea viruses isolated from clinical specimens. Revue Scientifique et Technique de l' Office International des Epizooties, 17:733-742.

FERREIRA, G.M., LOURENS, D.C. \& VAN VUUREN, M. 2000. The prevalence of bovine viral diarrhoea antibodies in selected South African dairy herds and control of the disease. Journal of South African Veterinary Association, 71: 10-13.

FLORES, E.F., WEIBLEN, R., GIL, L.H.V.G., TOBIAS, F.L., LIMA, M., GARCEZ, D.C. \& BOTTON, S.A. 2000. Antigenic diversity of Brazilian isolate of bovine viral diarrhoea virus (BVDV) implications for diagnosis and immunization strategies. Arquivo Brasileiro de Medicina Veterinaria e Zootecnia, 52:11-17.

GIANGASPERO, M., ALDERS, R., BAER, J., BLONDEL, H. \& MORGAN, D. 1991. Epidemiological survey of bovine virus diarrhoea (BVD) in Zambian cattle. Zimbabwe Veterinary Journal, 22:57-63. 
HORZINEK, M.C. 1991. Pestivirus-taxonomic perspectives. Archives of Virology, suppl. 3:55-65

LOWINGS, P., IBATA, G., NEEDHAM, J. \& PATON, D. 1996. Classical swine fever virus diversity and evolution. Journal of General Virology, 77:1311-1321.

MUVAVARIRWA, P., MUDENGE, D., MOYO, D. \& JAVANGWE, S. 1995. Detection of bovine viral diarrhoea virus antibodies in cattle with an enzyme-linked immunosorbent assay. Onderstepoort Journal of Veterinary Research, 62 241-244.

PATON, D.J. 1995. Pestivirus diversity. Journal of Comparative Pathology, 112:215-236.

PELLERIN, C., VANDENHURK, J., LECOMTE, J., TIJSSEN, P. 1994. Identification of a new group of bovine viral diarrhoea virus strains associated with severe outbreaks and high mortalities. Virology, 203:260-268.

RIDPATH, J.F., NEILL, J.D., FREY, M., LANDGRAF, J.G., THIEL, H.J. 2000. Phylogenetic antigenic and clinical characterization of type 2 BVDV from North America. Veterinary Microbiology, 77:145-155.

SULLIVAN, D.G., CHANG, G.J. \& AKKINA, R.K. 1997. Genetic characterization of ruminant pestiviruses: sequence anal- ysis of viral genotypes isolated from sheep. Virus Research, 47:19-29.

THEODORIDIS, A. \& BOSHOFF, S.E.T. 1974. Isolation of cytopathogenic strains of bovine viral diarrhoea virus in southern Africa. Journal of South African Veterinary Association, 445: 203-205.

THEODORIDIS, A., BOSHOFF, S.E.T. \& BOTHA, M.J. 1973. Mucosal disease in southern Africa. Journal of South African Veterinary Association, 44:61-63.

THIEL, H.J., PLAGEMANN, P. \& MOENNIG, V. 1996. Flaviviridae: Pestiviruses, in Virology, edited by B.N. Knipe \& D.N. Howley. Philadelphia: Raven Press.

VAN VUUREN, M. 1991. The microbiological diagnosis of respiratory tract infections in feedlot cattle in South Africa. MMedVet. thesis, University of Pretoria.

VILCEK, S., ALENIUS, S., PATON, D.J., MITTELHOLZER, C. \& BELÁK, S. 1999. Genetic clustering of bovine viral diarrhoea viruses in cattle farms: genetic identification and analysis of viruses directly from cattle sera. Veterinary Journal, 158:3338.

VILCEK, S., NETTLETON, P.F., PATON, D.J. \& BELÁK, S. 1997. Molecular characterization of ovine pestiviruses. Journal of General Virology, 78:725-735. 